\title{
SPECIAL DETACHMENTS \\ OF THE UKRAINIAN LIBERATION MOVEMENT IN 1944-1949: VISIONS OF MODERN SCHOLARS
}

\section{Ukhach Vasil $^{1}$}

DOI: https://doi.org/10.30525/978-9934-571-89-3_65

In the postwar period, the strategy and tactics specifics of the struggle of the Ukrainian liberation movement subjects with the punitive and power structures of the Soviet totalitarian regime in Western Ukraine led to the special role of the Security police of the Organization of Ukrainian nationalists (SB OUN(b)), which, according to D. Vedeneyev, "... ensured the implementation of the basic schemes of underground activities of the OUN" [2, p. 181]. Being formed as a "separate organizational unit", the SB OUN(b) administrative offices gained a special place in the underground system and had bundles of communication and work plans.

The purpose of the research is to analyze the modern domestic historians'studies of the special units activities of the Ukrainian liberation movement in one of the hottest periods of the confrontation with the punitive powers of the Soviet totalitarian regime in 1944-1949.

The outlined scientific subjects are presented in numerous scientific publications of contemporary Ukrainian historians. For example, in the works of Y. Antoniuk, D. Viedienieiev, V. Ilnytskyi, V. Yefymenko, O. Lysenko, V. Trofymovych and others.

Domestic historians claim that the major losses of the Ukrainian Insurgent Army (UPA) foremost forced the leadership of the Ukrainian liberation movement in November 1944 to give a sober reassessment of the previous struggle stage. In the list of outlined measures of further struggle I. Patrylyak defines the following statements: the nationalist underground should have held back positions and reorganize all structural units; should have reduced the number of administrative offices and made the OUN(b) network more mobile. The Ukrainian Insurgent Army had to refuse from regular military operations and "... finally turn into partisan-sabotage methods" [11, p. 434]. I. Patrylak also emphasizes the growing attention of the insurgent intelligence and counterintelligence command, which greatly intensified the influence of SB OUN(b) [11, p. 434].

During the winter of 1945-1946, the punitive structures of the Soviet totalitarian regime significantly depleted the strength position of the Ukrainian liberation movement through the system of military, ideological and political measures. The unequal difference of the warring parties potential, lack of international support sources for the OUN(b) and the UPA struggle and problems with growing, chronic fatigue of the population had a major influence on the situation. Despite the countermeasures taken by the SB OUN(b), the counterintelligence of the independent

${ }^{1}$ Ternopil National Economic University, Ukraine 
forces failed to respond adequately to the insidious agency-operational activities of the Soviet secret services [9, p. 386].

It should be emphasized that the activities of the $\mathrm{SB} \operatorname{OUN}(\mathrm{b})$ and of the intelligence services of the UPA in their post-war confrontation with the communist government and Soviet punitive structures are properly represented by monographic works of D. Viedeneev, (co-authored with V. Yegorov [3, p. 485-503] and G. Bystrukhin [4]). Their monograph is one of the first, which investigated a matter of the SB OUN(b) and UPA post-war activities on a solid source base from the archives of the SB OUN (b) and its regional departments. The monographic study of O. Ishchuk and V. Ogorodnik [7] is fully dedicated to the Mykola Arsenitch's activity - one of the organizers and leaders of the OUN(b). On the basis of processed archive materials, researchers state that "the activity of the SB OUN(b) was not systemless and senselessly cruel as Soviet propaganda claimed it to be. It was well organized, regulated by clear instructions and orders, which were personally approved by M. Arsenitch and other employees subordinated to him" [8, p. 286].

Y. Antoniuk carried out the regional natural history discourse on the activity of the SB OUN(b) in Volyn [1]. The author emphasized the preconditions for the formation, periodization and evolution of SB OUN (b) activity. In order to provide an adequate picture of the activities of the OUN secret services, Y. Antoniuk acknowledges that the SB OUN(b) was one of the most influential in the structure of the nationalist underground in the region and one of the strongest parts of the Ukrainian National Liberation Movement [1, p. 136].

An important scientific value is the publication of materials and documents on the activities of the SB OUN(b) in the 1940s. It was published under auspices of the Institute of History of Ukraine of the National Academy of Sciences of Ukraine and the Taras Shevchenko National University of Kyiv [10]. Document specialists O. Lysenko and I. Patrylyak included 21 documents on the history of the SB OUN(b) for the period of 1941-1947, revealed the evolution of the secret services tasks in different periods, stated that $\mathrm{SB} \operatorname{OUN}(\mathrm{b})$ activities made the national liberation struggle last for a decade longer [10, p. 294].

The historiographical analysis of the scientists` works makes it possible to outline the main theses, which determine activities of the SB OUN(b) and of the UPA intelligence service. Firstly, the organization of the secret services activity, their specific importance in the deployment of the national liberation struggle was caused by the extreme historical conditions of the fight against the Soviet punitive and military structures, the choice of both sides to use force methods to achieve their goals; the need to protect the organizational cells and cells of the underground, insurgent divisions; political differentiation and complicated internal relations, "the specifics of the ideology and socio-political mood of the movement participants of the OUN and the UPA" [5, p. 348]. Secondly, historians have been thoroughly researched the main organizational forms, key areas of activities, functional responsibilities of special units, the receptioned forms and methods of their operational work taken from the enemy-states special forces arsenal [5, p. 349]. Thirdly, activity of special detachments of Ukrainian nationalists "... was directed to 
intelligence and counterintelligence protection of the underground positions and to participate directly in counteraction to sovietization processes in the region" [4, p. 137]. Modern scholars objectively emphasize on the SB OUN (b) "cleansing" actions among the membership of the underground rebel movement [4, p. 138], mistakes, cruelties and reprisals against the local Ukrainian and Polish population [1, p. 135]. In this context, the conceptual and methodological significance comes from D. Viedeneyev and G. Bistrukhin works, which claim that “... both sides did not disregard the methods of inhumanity, and only then the victorious side, using propaganda, totally rewrote (or concealed) the history. Victorious side profitably interpreted events for themselves, glorifying themselves and in every way demonizing actions of the opponent" [6, p. 8]. Special forces of a non-state nature, as generalized by D. Vedeneev and G. Bistrukhin, are "... structural elements of national liberation and other governmental movements (organizations), their military formations, which carry out intelligence, counterintelligence, operational-combat and other specific functions that are typical to the special detachments in order to promote realization of the strategic and current tasks (of the mentioned movements or organizations) by using specific means" [6, p. 45-46].

Generally, contemporary Ukrainian historians are unanimous in concluding that the intelligence and control activities of the special detachments of the OUN underground and the Ukrainian Insurgent Army caused the development of the national liberation struggle and were one of the key factors that "... provided the duration, scale and fierce anti-Soviet resistance movement in the region" [4, p. 138].

\section{References:}

1. Antoniuk Ya. M., (2007). Diialnist Sluzhby bezpeky OUN. Istoryko-kraieznavche vydannia [Activities of the OUN Security police. Historical and local lore edition Activities of the OUN Security police. Historical and local lore edition]. Lutsk: Volynska knyha. (in Ukrainian)

2. Viedienieiev D. (2012). Pisliavoienna evoliutsiia stratehii, taktyky, orhanizatsiinofunktsionalnoi pobudovy ozbroienoho rukhu oporu pid provodom OUN(b) v Zakhidnii Ukraini [The post-war evolution of strategy, tactics, organizational and functional construction of the armed resistance movement under the leadership of the OUN(b) in Western Ukraine]. Ukraina: kulturna spadshchyna, natsionalna svidomist, derzhavnist, vol. 22, p. 181.

3. Viedienieiev D., Yehorov V. (2000). Mech i tryzub: Notatky do istorii sluzhby bezpeky Orhanizatsii Ukrainskykh Natsionalistiv [Sword and Trident: Notes on the History of the Secret Service of the Organization of Ukrainian nationalists]. $Z$ arkhiviv VUChK-HPU-NKVD-KHB, no. 2/4, pp. 485-503.

4. Viedienieiev D.V., Bystrukhin H.S., (2007). Dvobii bez kompromisiv. Protyborstvo spetspidrozdiliv OUN ta radianskykh syl spetsoperatsii. 1945-1980-ti roky [A duel without compromises. Confrontation of special detachments of the OUN and the Soviet forces special operations. 1945-1980s A duel without compromises. Confrontation of special detachments of the OUN and the Soviet forces special operations. 1945-1980s]. Kyiv: "K.I.S. ", pp. 137, 138. (in Ukrainian)

5. Viedienieiev D.V., Bystrukhin H.S. (2006). Mech i tryzub. Rozvidka i kontrrozvidka rukhu ukrainskykh natsionalistiv ta UPA (1920-1945) [Sword and trident. Intelligence and counterintelligence of the movement of Ukrainian nationalists and UPA (1920-1945)]. Kyiv: Heneza, pp. 348, 349. (in Ukrainian) 
6. Viedienieiev D.V., Bystrukhin H.S. (2007). "Povstanska rozvidka diie tochno y vidvazhno...". Dokumentalna spadshchyna pidrozdiliv spetsialnoho pryznachennia Orhanizatsii ukrainskykh natsionalistiv ta Ukrainskoi povstanskoi armii. 1940-1950-ti roky ["Insurgent intelligence operates precisely and courageously ...". The documentary legacy of special units of the Organization of Ukrainian Nationalists and the Ukrainian Insurgent Army. 1940-1950s]. Kyiv: "K.I.S.”. pp. 8, 45-46. (in Ukrainian)

7. Ishchuk O., Ohorodnik V. (2010). Heneral Mykola Arsenych: zhyttia ta diialnist shefa SB OUN [General Mykola Arsenitch: life and activities of the SB OUN chief]. Kolomyia: "Vik". (in Ukrainian)

8. Ilnytskyi V. (2015). Ukrainskyi natsionalno-vyzvolnyi rukh u Karpatskomu krai OUN (19451954): istoriohrafiia problemy [Ukrainian national liberation movement in the Carpathian land of the OUN (1945-1954): historiography of the problem]. Drohobytskyi kraieznavchyi zbirnyk. Spetsvypusk 2, p. 286.

9. Lysenko O. Ye. (2005). Borotba radianskykh sylovykh struktur proty OUN i UPA u 1945 r. Orhanizatsiia ukrainskyi natsionalistiv i ukrainska povstanska armiia. Istorychni narysy [The struggle of the Soviet security forces against the OUN and the UPA in 1945. Organization of Ukrainian nationalists and the Ukrainian insurgent army. Historical Essays]. Kyiv: Naukova dumka, p. 386. (in Ukrainian)

10. Lysenko O.Ye., Patryliak I. (2003). Materialy ta dokumenty Sluzhby bezpeky OUN(b) u 1940-kh rr. [Materials and documents of the OUN(b) Security police in the 1940's.]. Kyiv, p. 234. (in Ukrainian)

11. Patryliak I. (2012). "Peremoha abo smert": ukrainskyi vyzvolnyi rukh u 1939-1960 rokakh ["Victory or death": Ukrainian liberation movement in 1939-1960]. Lviv: Chasopys, p. 434. (in Ukrainian) 